
Africa

\title{
Alleviation or Politicization of Poverty in Africa? A Critique of Nigeria's Social Investments Programs under Buhari-led Administration, 2015-2020
}

\author{
Anthony Chinedu Ugwu ${ }^{*}$ Al Chukwuma Okoli ${ }^{* *}$
}

\begin{abstract}
The study interrogates the politics of poverty alleviation amidst the prevalence of poverty in Africa, focusing on Nigeria. Nigeria currently ranks among the poor countries in the world. While many studies have examined aspects of poverty mitigation within the national development frameworks, the politics underlying such endeavors have been under-explored. This study narrows this gap by investigating how politicians bastardize social investment programs through tokenish material 'hand-outs' designed to serve immediate political ends. The study is based on textual and contextual analysis of secondary sources, as complemented by corroborated anecdotes. Appropriating Marxian production theory, the study posits that the prevalence of poverty in Africa has been occasioned by macro and micro-level politics. At the macro-level, the balance of trade cum balance of payment asymmetries has reproduced conditions that perpetuate dependency and underdevelopment in the developing countries in general and Nigeria in particular. At the micro-level, local politicians trivialize social investments by exploiting the poverty situation of the populace for electoral gains through ad hoc material 'hand-outs.' This has weakened the social investment policy environment and alienated the citizenry in decision-making concerning wealth creation, distribution, and social investments priorities. The study recommends mainstreaming social investment governance into national development programing for sustainability.
\end{abstract}

Keywords: Nigeria, National Development, Politicization, Poverty, Social Investment.

\section{Introduction}

Public policy is at the core of governance in modern political systems. It is the process by which the authoritative allocation of values is made in that context (Easton, 1965). The essence of public policy is to promote the public good through the strategic deployment of powers and resources of the state (McLean \& McMillan, 2003). The expectation in this regard is that framers and operators of public policies should be guided by the dictates of civic rationality, selflessness, and due diligence to ensure the delivery of the public good.

The process of public policy in Africa has been somewhat ironic. Rather than advance national development, public policy in most African states has been associated with elements of 'bad politics.' According to Obanya (2010), these elements include the preeminence of politics over

\footnotetext{
* Federal University of Lafia, Nigeria. Email: chinedugwu5@gmail.com

** Federal University of Lafia, Nigeria. Email: okochu007@yahoo.com
} 


\section{PanAfrican Journal of Governance and Development, Vol. 2, No. 2, August 2021}

policy. Besides, the undue emphasis is on the political governance of policy rather than on its substance, the multiplication of structures for the management of the policy. There has been a tension between the imperative of public good and the exigencies of vested interests in most instances. So, instead of being a rational and strategic endeavor, policymaking and implementation in most African states, including Nigeria, have become a politicized venture characterized by political patronage and partisan syndrome. In addition to the syndrome, Ngwu (2012) further explained that in most instances, the most significant impediments to effective public policy implementation are the legal instruments from which such policies derive their beings.

The contradictions of public policy in Africa are such that despite the usual lofty goals espoused in a policy, the outcome hardly brings about the desired end. This has been the situation with social investments policy in Nigeria since 1989 when the social development policy was crafted. In that policy document, social development was defined as:

The process of continuous improvement of the social structure, institutions, and programs in order to create a societal condition in which the rights of citizens are advanced and protected; their welfare enhanced; and their effective functioning and self-actualization ensured (Social Development Policy for Nigeria, 1989, p.3).

Without ado, the above idea is what gives legitimacy to any form of government, and the task of this paper is to examine the social development climate in Nigeria under the current administration led by President Muhamadu Buhari (2015-2020). Since its inception, Buhari's government has launched a number of social development programs christened the NationalSocial Investment Program (N-SIP), aimed at poverty reduction and sustainable human development. The paper evaluates the strategic efficacy of these programs, intending to ascertain if the efforts have amounted to poverty mitigation or politicization.

The remainder of the paper is thematically structured into three broad sections. The following section considers conceptual, theoretical, and contextual issues in an attempt to situate the epistemological background to the discourse. This is followed by the exploration of the literature and the analysis of the substantive issue. The last section looks at the policy implications of the analysis and conclusion. 


\section{Research Methodology}

This paper is an exploratory critical discourse on the efficacy of social investment and poverty alleviation programming in Africa, particularly Nigeria. It engages Nigeria's social investment policy and programs under the current administration led by President Mohammadu Buhari to situate their successes, challenges, and prospects. The paper is a product of desk research that relied on textual and contextual engagements with the literature and relevant policy documents to deliver its analysis. The thrust of the analysis is prosecuted thematically, with the aid of descriptive data that are qualitatively harnessed to substantiate the underlying arguments. The analysis is premised on salient assumptions of Marxian theory of social production as contextualized within the pathology of Africa's post-colonial developmental problem. The peculiar nature and outlook of the paper as a socially conscious policy-cum-advocacy analysis has necessitated an analytical bent towards an evaluative and prescriptive discourse.

\section{Frame of Reference}

Three key terms constitute the frame of reference in this paper, namely, politicization, poverty, and social investment. This section (Table 1) considers these terms to conceptualize them based on their operational applications in the context of the present discourse.

\section{Table 1: Conceptualizing the Basic Terms}

\begin{tabular}{|l|l|}
\hline Term & Conceptualization \\
\hline Politicization & $\begin{array}{l}\text { Politicization bears positive as well as negative connotations. In a positive } \\
\text { sense, it implies prioritizing a matter as a strategic policy issue (Bebbington, } \\
\text { 2006; Busso, 2017). In the negative sense, it refers to the abuse of a policy } \\
\text { process or an issue thereof through political patronage and partisanship (Okoli } \\
\text { \& Orinya, 2014). Politicization is understood and applied herewith in its } \\
\text { negative sense. }\end{array}$ \\
\hline Poverty & $\begin{array}{l}\text { Poverty refers to the condition of material lack, whereby a person or a } \\
\text { population cannot sustainably meet its basic existential needs. The meaning of } \\
\text { poverty in this context encompasses a lack of access to basic and sustainable } \\
\text { livelihood as well as socio-economic entitlements that guarantee sustainable } \\
\text { livelihood (Harriss, 2007). }\end{array}$ \\
\hline $\begin{array}{l}\text { Social } \\
\text { investment }\end{array}$ & $\begin{array}{l}\text { Social investment is the deployment of investment capital to create social } \\
\text { returns in terms of secured livelihood, economic empowerment, and social } \\
\text { uplift (NSIO, 2018). This is achieved through interventionist programs } \\
\text { targeting vulnerable social strata in critical socio-economic standing, such as } \\
\text { the youths, rural women, and other vulnerable populations. }\end{array}$ \\
\hline
\end{tabular}

Source: Authors' corroborations with the various authorities cited in-text. 


\section{PanAfrican Journal of Governance and Development, Vol. 2, No. 2, August 2021}

\section{Literature Review}

\section{Perspectives on Poverty and Social Investment}

Poverty has assumed multidimensional implications for human security and development worldwide, especially in developing countries. About Africa, Okpeh, Ikoh, Onaji-Benson, and Ikase (2019) noted that:

Africa is the most poverty-ridden continent in the world. There are several glaring but worrisome statistics in the public domain to prove the assertion. For instance, in the period 1960-1970, 20 out of 30 least developed countries were in Africa; 12 of these countries had negative Gross Domestic Product (GDP) per capita. In the period 1970-1976, 20 African countries had negative growth rates. For the period 1960-1979, 8 African countries had negative annual growth rate per capita; others had growth rates per capita ranging from $0-1 \%$ and $1 \%$ and $2 \%$ (p.viii).

The scenario above was Africa in the immediate post-colonial era, and as such, it carries a lot of concerns regarding the quality of independence that she got from her colonial lords. Nigeria, in particular, has a lot to worry about as her statistics are not different from the scenario above. According to Onah and Olise (2019, p.1), "about 100 million Nigerians (62.6 percent of the population) live below the international poverty line (PPP US\$1.25 per day)". This is notwithstanding that the Nigerian GDP growth rate was observed at an average of $8 \%$ a year between 2000 and 2013. During the same period, per capita income more than quadrupled from US\$646 to US\$2,937, nearly triple the rate of population growth (CDD, 2019, p.2), but unfortunately, the poverty rate has maintained a negative trend.

Micro, Small, and Medium Enterprises (MSMEs) sector were to revert this trend as it was observed to have contributed about $52 \%$ of GDP and employed $82 \%$ of Nigeria's workforce in 2014. However, the lack of adequate support to the sector posed an enormous challenge to the Nigerian economy. It was noted that:

Regarding access to credit for development, less than 5\% of credit from financial institutions went to MSMEs, leaving about 89\% of the 37 million enterprises in this sector without access to credit from the formal financial sector. This severely limited their capacity to grow, increase value 

Africa

addition, modernize processes and technology and boost employment creation (DBN, 2017 in CDD, 2019, p.3).

This equally got sundry social challenges in Nigeria. Unemployment doubled from 6.4 percent in 2014 to 14.2 percent in 2017 (FGN, 2017, p.16). There was also a high rate of inequality (GINI Coefficient of 43 percent) not just with respect to income but also in terms of access to basic social services and opportunities. This was the state of the Nigerian economy when the Buhariled administration took over power following a democratic election in 2015 and after that felt compelled to initiate national social investment policy. Unfortunately, the situation has got more complicated as the country has witnessed a high level of insecurity ranging from Boko Haram insurgency, herders attack, banditry, cattle rustling, kidnapping, and others.

Many African countries are also mired in this Nigeria's debilitating socio-economic situation. Thus, Fwatshak (2011, p. 70) noted that "Africa's foreign debts represents up to 80\% of GDP, inflation rates average between 12-45\%, unemployment rates (excluding the informal sector) ranges between 12 and $25 \%$, while the saving rate is the lowest in the world". In the same vein, Ihonvbere (2011) observed that 15 of the world's 20 most impoverished nations are in Africa, with over 3 million refugees and 18 million internally displaced persons. International agencies estimate that over 250 million have no access to potable water, while over 200 million have no access to basic health services. More than 2 million children die before their first year; over 150 million youths are illiterates. The World Bank (as cited in Agwuele, 2011) summarizes the African predicament thus:

The continent is noted for being a cauldron of poverty, conflicts, wars, and death. African geopolitics is characterized by forlorn, dysfunctional, and conflict-ridden failed states. Africa sustains the least frontiers of backwaters in the global calculation, despite its abundant human and natural resources and more cultivable land than any region in the world. African states have also received an estimated \$1 trillion in foreign aid since independence and yet have slid into near abysmal poverty and underdevelopment (p. 89). 


\section{PanAfrican Journal of Governance and Development, Vol. 2, No. 2, August 2021}

The African predicament, as presented, shows a continent that lags behind all other continents, especially in terms of poverty tackling and development provisioning. African countries had to borrow to close the gap, which compounded their predicaments, as Fwatshak (2011) elaborately observed. In the case of Nigeria, the Debt Management Office (DMO) (2020, p.7) recorded that:

Between 2015 and December 2020, Nigeria's external debt profile has risen from $\$ 9.7$ billion to $\$ 27$ billion. Most of these were borrowed in the first four years of President Muhammadu Buhari's Presidency via multilateral, development, bilateral, and commercial loans). Nigeria's total debt profile rose to $N 31,009$ trillion (\$85. 897 billion) as of June, 2020. The figure comprises the debt stock of the Federal government, 36 states of the federation, and the federal capital territory, Abuja.

This period falls within President Buhari's first tenure and part of his second tenure as Nigeria's civilian President. Furthermore, the DMO report (2020) expects the public debt stock to grow as the balance of the new domestic borrowing is raised and expected disbursements are made by the World Bank, African Development Bank, and the Islamic Bank, which arranged to finance the 2020 budget. This expectation came to fulfillment and was documented in DMO (2021)'s release. Therein, Nigeria's Public Debt Stock as of March 31, 2021, stood at N33.107 trillion or USD87.239 billion.

While there may exist genuine reasons for borrowing, the spree for it by Nigerian leaders is worrisome, especially as there exists little or no evidence in terms of capital projects or human development and security as stipulated by Nigeria's Fiscal Responsibility Act, 2007. Since Nigerian political elites have been notorious for fiscal irresponsibility and indiscipline, as Urama, Iloh, and Ekeocha (2018) noted, the consequences have been ever-increasing poverty rate and the likes.

The global trend for combating the predicament of poverty worldwide consists of the plethora of social investment packages that various countries in the world have adopted to manage such malaise towards total eradication. The Sustainable Development Goals (SDGs), which have naturally succeeded the Millennium Development Goals (MDGs), are universal initiatives to eradicate poverty and improve sustainable livelihood based on some indicators and targets. 
Applying social investment policies and programs to achieve the laudable indicators and targets has elicited views of scholars from an array of schools of thought. The debate has been about whether a social investment has been a better strategy to reconcile the goals of employment, growth, and social inclusion. In recent years, some scholars have criticized the social investment approach for not being able to achieve its intended distributional consequences. These scholars have also raised doubts about whether the social investment goals of increasing employment and decreasing poverty are reconcilable. However, other scholars hold that the merits of social investment have remained popular both in developed and developing countries.

In advancement of the popularity of the social investment approach, Cronert and Palme (2017) noted that:

For over the past 15 years, the concept of 'social investment' has gradually gained traction among European Union policymakers. Here, social investment-oriented policies aimed at enhancing the productive capacity and employments of the population have been identified as key elements in a strategy to increase growth and competitiveness and reduce poverty and social exclusion. Central strategies and policy agendas, such as the Lisbon Agenda of 2000, the Europe 2020 strategy of 2010, and the Social Investment Package of 2013, are all manifestations.

The context above is quite vocal on the appreciation of the merits of social investment for which policymakers in Europe have tied the continent's future. The policymakers hold that social investment-oriented services go a long way to achieve egalitarian redistribution in society. Scholars who support this view include Esping-Andersen and Myles (2009), who found that services are generally redistributive but less so than some cash transfers, whereas Verbist and Matsaganis (2014) found that the poverty-reducing effect of services is much larger than the one of cash transfers to the working-age population. Nelson and Stephens (2012) find that a range of social investment-oriented services is positively related to the consequent level of general skills especially in the bottom half of the skill distribution - and to both the employment levels in general and employment in knowledge-intensive services. Using concentration coefficients, they show that although the design of cash transfers in most cases make them more oriented toward lower-income groups, services are much more important in size. 


\section{PanAfrican Journal of Governance and Development, Vol. 2, No. 2, August 2021}

The argument on the distributive consequences of social investments has elicited reactions in recent scholarly debates, particularly on its consequences for poverty, which have received the most skepticism (Cronert \& Palme, 2017). Many factors have been brought up that might have a detrimental effect on poverty and are typically held to be intrinsic to the social investment approach. However, some of these concerns primarily have a bearing on either the particular principles or policy prescriptions, which according to Cronert \& Palme (2017), are linked to the Third Way approach or the consequences of 'activation' reforms introduced across Europe over the past two decades; most of which have had very little investment content according to De la Porte and Jacobsson (2012). Other scholars whose views do not support social investment service-oriented policies and programs include Vandenbroucke and Vleminckx (2011), Cantillon (2011), Corluy and Vandenbroucke (2014), and de Beer (2007). Their postulations have been itemized as follows.

- First, it has been argued that because the consumption of those public services associated with the social investment approach is typically work-related and earnings-related, such services have a less redistributive profile than traditional cash transfers, giving way to 'Matthew effects' and increasing inequalities in social investment-oriented states (Cantillon, 2011).

- Second, it has been argued that the shift on the political agenda from passive income support policies to active investment policies has resulted in a reallocation of resources away from the more redistributive policy areas to the less so.

- Third, it has been argued that the discursive emphasis on 'making work pay' has justified, and perhaps even necessitated, a re-commodification of citizens by means of retrenchment of benefits, with detrimental consequences for the more vulnerable (Vandenbroucke \& Vleminckx, 2011).

- Fourth, it has been argued that while on an aggregate level these consequences could have been mitigated in case the policies were successful in moving unemployed people into employment, the proportion of people living in jobless households has hardly decreased in the EU in the wake of the employment and inclusion strategies, despite rising overall employment rates. This has raised doubts about whether the goals of increasing employment and decreasing poverty underpinning the social investment 

Africa

approach are reconcilable (Cantillon, 2011; Corluy \& Vandenbroucke, 2014; de Beer, 2007).

In sum, existing evidence seems to suggest that in general, the distributional profile of social investment-oriented services, as discussed by Cronert and Palme (2017), scrutinized two different versions of the social investment approach identified as the 'Nordic approach' (cf. Esping-Andersen et al., 2002) and the 'Third Way Approach' pioneered by Giddens (1998). It is a function of their content and targeting and the national context in which they are implemented. Thus, the potential of social investment to reduce poverty is not in doubt, but who implements the policies and how the policies are implemented are fundamental in the success or otherwise of any social investment programs. Giddens (1998) has said that the Third Way rejects the state socialist conception of socialism as a form of economic determinism espoused by Karl Marx. It instead accepts the conception of socialism as:

An ethical doctrine that views social-democratic governments as having achieved viable ethical socialism abhors capitalism's unjust elements by providing social welfare and other policies like egalitarianism in society through action to increase the distribution of skills, capacities, and productive endowments. It emphasizes commitment to balanced budgets, providing equal opportunity, which is combined with an emphasis on personal responsibility, the decentralization of government power to the lowest level possible, encouragement and promotion of public-private partnerships, improving labor supply, investment in human development, preserving of social capital and protection of the environment (Rosenau, 2003, p.209).

These ethically laden words furthered Giddens's radical approach to politics of welfare to the citizens by the European States and beyond. As in Europe, social investment policies and programs have assumed an air of importance among the countries in the global South and eminently so in Africa. In this recognition, Samson (2013) observed that countries of the South over the past decade have increasingly recognized the importance of social protection for ensuring that development reaches all members of society, especially the poor. A growing number and range of programs are channeled such as cash transfers by the government to the 


\section{PanAfrican Journal of Governance and Development, Vol. 2, No. 2, August 2021}

poorest sectors of society and health insurance. In Africa alone, the number of cash transfer programs increased ten-fold between 2000 and 2009 - from 25 in 9 countries to 245 in 41 countries (Garcia \& Moore, 2012).

Other developing countries in Asia and Latin American continents have also established Conditional Cash Transfer (CCT) programs and recent qualitative studies on them affirm their viability for social protection. Here, we recall evaluative studies by IEG (2011), Fiszbein et al. (2009), Rawlings and Rubio (2005), which submitted that; on the whole, CCT programs have positive effects on schooling (enrollment, attendance, dropout) and health (vaccinations, medical check-up) outcomes. These reviews also indicate substantial variation in effect sizes between countries and among different population groups within countries (for example, gender, age, or urban vs. rural residence). These studies evaluated programs in Bangladesh, Nicaragua, Mexico, and Brazil. The studies noted that while the basic structure of CCTs is essentially the same, specific design features vary considerably across programs and countries. Specific individual evaluations suggest that program design features such as transfer amounts (Filmer \& Schady, 2009a), the timing of payments (Barrera-Osorio, Bertrand, Perez-Calle \& Linden, 2009), or whether there is a supply-side intervention (Filmer \& Schady, 2009b; Glewwe \& Olinto, 2004) explain specific patterns of treatment effect heterogeneity. However, the overriding impact is that CCTs have been positive on poverty reduction where it was applied with genuine intent that accommodates the supply and demand sides since they are crucial in determining the program's long-term effects. Britto (2005) made it clear that:

The mere fact that more children go to school does not necessarily translate into higher educational attainment and, in turn, the translation of higher educational attainment into higher earnings cannot be taken for granted, as it is mediated by the quality of education received, rates of employment, absorption of skilled labor in the economic structure and general rates of return to education (p.13).

This idea is crucial as the pro-Welfare State scholars have based their argument against social investment on the temporality of its impact and its limited redistributive capacity to transform the poverty situation. Thus, incentivization towards school enrolment and attendance will be appreciated to the extent of the quality of education provisioning. 

Africa

Furthermore, in their examination of the relationship between the developments in social investment policies and the variations in poverty and income inequality across countries and over time, Van Vliet and Chen (2015) suggest that the detrimental effect of social investment policies, described in some specific cases in the literature, cannot be generalized. This submission came from a study of 15 European countries relying on EU ECHP/SILC1 data and data from the OECD (2012a) Social Expenditure Database.

\section{Theoretical Framework: Marxian Theory of Social Production}

The theory of social production was propounded by Karl Marx (1818-1883), wherein he postulated that the basic principles of history are hinged on the economic environments in which societies develop. Marx used the term mode of production to refer to the specific organization of economic production in a given society. The mode of production determines politics and social and cultural life (Igwe, 2005, p.353). A mode of production includes the means of production used by a given society, such as factories and other facilities, machines, and raw materials. It also includes labor and the organization of the labor force. The relation of production refers to the relationship between those who own the means of production (the capitalists or bourgeoisie) and those who do not (the workers or the proletariat). According to Karl Marx, history evolves through the interaction between the mode of production and the relations of production. The mode of production constantly evolves toward a realization of its fullest productive capacity. Capitalism is a mode of production based on private ownership of the means of production by the capitalists. Capitalists produce commodities for the exchange market and, to stay competitive and realize the fullest productive capacity, must extract as much labor from the workers as possible at the lowest possible cost. The economic interest of the capitalist is to pay the worker as little as possible, in fact just enough to keep him alive and productive. The workers, in turn, come to understand that their economic interest lies in preventing the capitalist from exploiting them in this way. Implicit in this is the scenario that the social relations of production are inherently tenuous and antagonistic, giving rise to a class struggle that Marx believes will lead to the overthrow of capitalism by the proletariat.

In applying this theory to our study, it is arguable that Nigeria is a capitalist state, and so it is with most African countries (Jimoh \& Olanrewaju, 2009). However, Nigeria's existence within a capitalist global economy renders it susceptible to the features of capitalism. Within the global 


\section{PanAfrican Journal of Governance and Development, Vol. 2, No. 2, August 2021}

economy, capitalist countries control the movement of goods and capital (money) around the world. Countries that immediately prominently come to mind here are America, Britain, Japan, Germany, Russia, China, France, and their likes (World Population Review, 2021). The relationship between Africa and particularly Nigeria, and these countries is complex of mutual benefits. The less advanced countries are of interest to the capitalist powers to the extent that they facilitate capital accumulation in the metropolitan or advanced capitalist countries. The metropolitan countries find Nigeria a dumping ground for their goods and a good source of cheap raw materials. Nigeria, a peripheral capitalist, does not have the wherewithal to bargain or negotiate with the 'core' or capitalist countries.

The core countries are politically, economically, scientifically, and technologically more advanced than Nigeria and other countries within the African continent. No wonder Ihonvbere (2011) noted that at the beginning of the new millennium, Africa was the poorest, most technologically backward, most politically unstable, most crisis-ridden, most indebted, and most foreign-dominated and exploited, as well as the most marginal continent in the world. This has bequeathed Africa, ipso facto Nigeria, with a dependent status. Ozor (2008) noted that:

This dependency describes the extent to which an economy is structurally disadvantaged in the international division of labor, that it lacks the autonomous capacity to exploit, control, and manage its natural, economic, and human resources without falling prey to the dictates of foreign economic and other interests (p.90).

It is, thus, apparent that the phenomenon of dependency that entangles Nigeria is a logical outcome of orchestrated imperialism and colonialism (Ozo, 2008). In this present global reality, Nigeria accepts virtually whatever conditionalities she is given in her strive towards socioeconomic development and her quest to remain within the modern state orbit. For this reason, Nigeria's efforts at development and fight against poverty have always followed a foreign design hardly embodying any autochthonous ideas and initiatives capable of reflecting the peculiarities of her environment. This accounts largely for why Nigeria and most African countries still suffer from the hemorrhage of poverty since her development initiatives or processes depend on outside factors or stimuli either of capital or expertise. 
At home, the character of Nigerian politics and politicians tend to have negated efforts at mitigating poverty. The social investment policies and programs have hardly impacted positively on the poor; they are mere palliatives to keep them from organized protests capable of overthrowing the pro-capitalist political class. By its nature, social investments in Nigeria have remained ad-hoc, parochial, and self-serving for the political class who by and large views the electorates as a commodity to be bought and sold as the capitalists do. This fetish obsession with money and commodity led the Nigerian political class into excessive primitive accumulation with the result that inequality between the poor and the rich ranks worst in the world. This shows the extent of government lip service to social welfare issues in Nigeria. In this regard, Idyorough (2019) noted that:

All political parties in Nigeria have welfare issues on the agenda in their manifestoes, and they do deploy all sorts of political rhetorics to woo votes from citizens. At the end of it all, the welfare issues are neglected, and in its place, the politicians go home with rich pockets. Annual budgets are prepared and approved by them. Yet the amount budgeted and released for welfare remains meager and hardly enough to meet our welfare needs. An evaluation of the annual budgetary allocation to the social welfare sector from [the] 2014 budget to 2018 clearly shows the neglect of this sector (p. 344).

The lack of political will compounds this neglect to address social welfare despite capturing it in chapter two of the 1999 constitution of Nigeria, which has not become justiciable. Under the present administration led by President Muhammadu Buhari, social investment has been further casualized and caricatured. The social investment programs include N-Power, N-YES, TraderMoni, Government Enterprise, and Empowerment Program (GEEP), a.k.a. MarketMoni, Conditional Cash Transfer (CCT), Home Grown School Feeding Program (SFP).

Of these programs, only four were activated towards the 2019 general elections, where first degree and postgraduate degree graduates were offered two years of employment for a monthly remuneration of 30,000 (thirty thousand nairas). Amidst this program implementation, Nigeria ranked the poorest country in the world after India (Kazeem, 2018, Busayo, Azuh, Olaronke, Ogundipe, Bowale, \& Azuh, 2021). 


\section{PanAfrican Journal of Governance and Development, Vol. 2, No. 2, August 2021}

This further validates Cunningham's (2007) assertion that there will always be poverty, irrespective of any half-hearted attempts to alleviate it by the welfare state. This trend has aptly validated the choice of this theory by Marx and the Marxists, who established the source of poverty in the structural essence of society; they identify the welfare system as an instrument of the state, which acts to maintain gross inequalities of wealth that see some people living in dire destitution with little chance of ever really escaping from it (Okoli \& Orinya, 2014). In Nigeria, it has been proven beyond doubt that while the welfare packages from the social investment programs of President Muhammadu Buhari-led's administration are on course, poverty still surges in the country. Odewale (2021) notes that the social and welfare programs for the unemployed and less privileged serve as a panacea to the perennial unemployment problem in Nigeria, have not been effective. Substantiating this claim, Odewale (2021) recalled that the National Bureau of Statistics (NBS) on Friday, August 14, 2020, released the statistics on unemployment for the second quarter, Q2, of 2020 after a long hiatus since the third quarter, Q3, of 2018. Therein, the percentage of unemployed people stood at $27.1 \%$, which shows a worsening situation from the previous release in 2018, where the percentage of the unemployed was 23\%. Apparently, within two years, the unemployment rate in Nigeria rose by $4 \%$ despite the social investment programs which in Muhammadu Buhari's Manifesto would lift three million Nigerians out of poverty by creating three million jobs.

\section{Nigeria's Poverty Profile: An Overview}

Nigeria is a resource-endowed nation grappling with the paradox of plenty syndrome. Despite her ebullient human and natural resource endowments, Nigeria still parades one of the world's worst development indicators. According to a World Bank's World Poverty Clock report published in June 2018, Nigeria is the poorest country on earth based on the percentage of her population exposed to extreme poverty (Kazeem, 2018, P.1; Table 2). Recent figures indicate that $45.7 \%$ of Nigerians live within extreme poverty (Babalola, 2018, p.3).

Table 2: Top 10 Poverty-stricken Countries of the World

\begin{tabular}{|l|l|l|}
\hline Rank & Country & \% of population below the poverty line \\
\hline $1^{\text {st }}$ & Nigeria & 86.9 million \\
\hline $2^{\text {nd }}$ & India & 71.5 \\
\hline $3^{\text {rd }}$ & Democratic Republic of Congo & 60.9 \\
\hline $4^{\text {th }}$ & Ethiopia & 23.9 \\
\hline
\end{tabular}


Anthony Chinedu U. \& Al Chukwuma O., Alleviation or Politicization of Poverty in Africa

\begin{tabular}{|l|l|l|}
\hline $5^{\text {th }}$ & Tanzania & 19.9 \\
\hline $6^{\text {th }}$ & Mozambique & 17.8 \\
\hline $7^{\text {th }}$ & Bangladesh & 17 \\
\hline $8^{\text {th }}$ & Kenya & 14.7 \\
\hline $9^{\text {th }}$ & Indonesia & 14.2 \\
\hline $10^{\text {th }}$ & Uganda & 14.2 \\
\hline
\end{tabular}

Source: World Bank's World Poverty Clock (2018).

By the World Bank's standard index, any individual who lives below the threshold of $\$ 1.9$ per day is considered to be extremely poor. In line with this yardstick, the bank reported that Nigeria has the highest number of extremely poor persons in the world, following results from its 2018 World Poverty Clock, which indicated that 86.99 million Nigerians live below the extreme poverty line. By these statistics, Nigeria has overtaken India as the world's poverty headquarters (cf. Table 2).

In addition to its abysmal national poverty profile, Nigeria also parades some dismal Human Development Indices (HDI). A recent UNDP report shows that Nigeria's HDI status has largely fallen below the global average across several critical indicators, including life expectancy, expected years in school, and per capita income (Table 3). Besides these macro-economic indices, Nigeria is equally faring so severely in salient aspects of human security, such as food and nutrition, healthcare, livelihood, and the like (UNDP (2018).

Table 3: Nigeria's HDI trends (1990-2017)

\begin{tabular}{|l|l|l|l|l|l|}
\hline Year & $\begin{array}{l}\text { Life expectancy } \\
\text { at birth }\end{array}$ & $\begin{array}{l}\text { Expected years } \\
\text { of schooling }\end{array}$ & $\begin{array}{l}\text { Mean years of } \\
\text { Schooling }\end{array}$ & $\begin{array}{l}\text { GNI per capita } \\
(2011 \text { PPP\$) }\end{array}$ & HDI value \\
\hline 1990 & 45.9 & 6.7 & & 2,792 & \\
\hline 1995 & 45.9 & 7.2 & & 2,569 & \\
\hline 2000 & 46.3 & 8.0 & & 2,451 & \\
\hline 2005 & 48.2 & 9.0 & 5.2 & 3,669 & 0.465 \\
\hline 2010 & 50.8 & 8.4 & 5.2 & 4,862 & 0.484 \\
\hline 2015 & 53.0 & 10.0 & 6.0 & 5,527 & 0.527 \\
\hline 2016 & 53.4 & 10.0 & 6.2 & 5,326 & 0.530 \\
\hline 2017 & 53.9 & 10.0 & 6.2 & 5,231 & 0.532 \\
\hline
\end{tabular}

Source: UNDP (2018:2). 


\section{PanAfrican Journal of Governance and Development, Vol. 2, No. 2, August 2021}

Note: The above statistics are based on consistent time series data and new goalposts. By this record, Nigeria's HDI value for 2017 is 0.532 - which places the country in the low human development category - positioning it at 157 out of 189 countries and territories surveyed (UNDP, 2018:2). However, between 2005 and 2017, Nigeria's HDI value rose from 0.465 to 0.532 , which amounts to an increase of 14.4 percent. As Table 2 also indicates, between 1990 and 2017, Nigeria's life expectancy at birth increased by 8.0 years; mean years of schooling increased by 1 year; expected years of schooling increased by 3.3 years, and GNI per capita increased by about 87.4 percent between 1990 and 2017. Despite the apparent progress in HDI, the country's poverty profile has remained persistently low.

\section{Understanding Buhari's National Social Investment Programs (N-SIP)}

The 2015 general elections in the Federal Republic of Nigeria brought in the government of President Muhammadu Buhari (GCFR). Shadare (2017) recalled that:

In the course of the last presidential campaign in Nigeria, which saw the People's Democratic Party overthrown for the first time since the return to democracy in 1999, the candidate for the All Progressive Congress promised a direct cash transfer to the poorest citizens. While pundits and critics generally viewed it as an unrealizable promise designed to win votes, it seems that Nigeria could be on the cusp of a social protection transformation (p.1).

Upon assumption of office, the Federal government under President Buhari unveiled four programs christened National Social Investment Programs (N-SIP). The programs are designed to draw from the social protection policy framework to ensure a life of dignity for those constrained in one way or another from achieving their full potential (FGN, 2017). Below is a graphical brief on each of the four major social investment programs administered by the Muhammadu Buhari-led administration since 2016.

Table 4: Overview of Buhari's National Social Investment Programs, 2015-2020

\begin{tabular}{|l|l|l|l|}
\hline S/N & Program & \multicolumn{1}{|c|}{ Objective } & \multicolumn{1}{c|}{ Target } \\
\hline 1. & N-Power & $\begin{array}{l}\text { N-Power is designed to help young } \\
\text { Nigerians acquire and develop life-long } \\
\text { skills to become solution providers in their } \\
\text { communities and players in the domestic } \\
\text { and global markets. }\end{array}$ & $\begin{array}{l}\text { N-Power Corps:500,000 } \\
\text { N-Power } \\
\text { Knowledge:25, 000 } \\
\text { N-Power Build: } 75,000\end{array}$ \\
\hline 2. & $\begin{array}{l}\text { Home Grown } \\
\text { School }\end{array}$ & $\begin{array}{l}\text { The program aimed at increasing } \\
\text { enrolment and completion rate at the } \\
\text { primary school level. It will also help to }\end{array}$ & $\begin{array}{l}\text { 5.5 million } \\
\text { primary school } \\
\text { pupils }\end{array}$ \\
\hline
\end{tabular}



Africa

\begin{tabular}{|c|c|c|c|}
\hline & $\begin{array}{l}\text { Program } \\
\text { (HGSFP) }\end{array}$ & $\begin{array}{l}\text { create jobs (via recruitment of cooks) and } \\
\text { raise agricultural demand since the } \\
\text { program is a key to building a value chain. } \\
\text { The manufacturers of utensils for cooks } \\
\text { and feeding are also another added value. }\end{array}$ & \\
\hline 3. & $\begin{array}{l}\text { Conditiona } \\
\text { l Cash } \\
\text { Transfer } \\
(\mathrm{CCT})\end{array}$ & $\begin{array}{l}\text { The program aims to target transfers to } \\
\text { poor and vulnerable households, with the } \\
\text { final aim of graduating them out of } \\
\text { poverty. }\end{array}$ & $\begin{array}{l}1 \text { million households to } \\
\text { receive N5,000 monthly as } \\
\text { conditional cash transfers. } \\
\text { Additional } 200,000 \\
\text { households and livelihood } \\
\text { support will be provided } \\
\text { through world } \\
\text { Bank credit (upon } \\
\text { approval of } \\
\text { borrowing plan) }\end{array}$ \\
\hline 4. & $\begin{array}{l}\text { Government } \\
\text { Enterprise } \\
\text { and } \\
\text { Empowerme } \\
\text { nt Program } \\
\text { (GEEP) } \\
\text { a.k.a. } \\
\text { MarketMoni } \\
\end{array}$ & $\begin{array}{l}\text { The program aimed at providing } \\
\text { financial services access to traders, } \\
\text { market women and women cooperatives; } \\
\text { artisans and MSMEs; enterprising } \\
\text { clusters/youth, farmers, and agric } \\
\text { workers }\end{array}$ & $\begin{array}{l}1 \text { million traders, women } \\
\text { Cooperatives and market } \\
\text { women 200,000 MSMEs; } \\
260,000 \text { enterprising youth; } \\
200,000 \text { farmers and agric } \\
\text { workers. }\end{array}$ \\
\hline
\end{tabular}

Source: Compiled from the National Social Investment Program's website:

https://nasims.gov.ng

\section{Evaluating Buhari's Social Investments Package (N-SIP): Poverty Mitigation or Politicization?}

Opinions have remained divided on the performance of these programs in relation to their stated objectives, mainly as they concern poverty mitigation. With over twenty international and local collaborators from public and private sectors of the economy, the N-SIP is undoubtedly ambitious and arguably more ambitious than over 26 earlier social protection programs under erstwhile administrations. The programs partners under the President Muhammadu Buhari administration in Nigeria include the World Bank, Actionaid, Bill \& Melinda Gates, Rockefeller Philanthropy Advisors, Dangote Group, MacArthur Foundation, Ford Foundation, UNICEF, The Nigeria Economic Summit Group (NESG), Lagos Business School, The Partnership for Child Development (PCD), Department for International Development (DfID), IITA, and others (FGN, 2019). 


\section{PanAfrican Journal of Governance and Development, Vol. 2, No. 2, August 2021}

However, the performance of the programs has left curious minds unsatisfactory. Scholars and social commentators, including MurtalaAdogi Mohammed, forewarned that the success of the programs would largely depend on professionalism instead of politics. According to him,

Most Nigerian politicians have no sense of social protection, so they cannot even think of designing, and much less, implementing programs aimed at attacking poverty frontally... to them, this is something new, and (my) suggest(ion) must be handled (sic) with care. Some of my concerns are Nigerian factors such as the politicization of the beneficiaries' selection process, weak public-civil servant capacity, weak institutions at the state and local level to coordinate the scheme; all these are something worth noting (Adogi, 2016, p.1)

This caution that came very timely before the full commencement of these programs captured the nature and character of development administration within Nigeria's socio-political ecology. The fragility of the public administration environment in the country has made the delivery of the common good associated with social investment programs very precarious. The political will that is needed to drive the programs to their logical conclusions is hardly manifested by the political elites. Thus, social protection in the country remains more of a political instrument deployed by politicians for attracting political support from the external environment and votes during elections than a genuine strategy for alleviating poverty in Nigeria (Okoli \& Ugwu, 2016).

A look at the development of social protection in the country reveals this line of argument. Social protection programs in Nigeria have a history as old as the late 80s, though; in its current form, it could be said to have begun in 2004, yet, it has been unable to acquire the desired momentum that should drive it. Every government since 2004 has made an effort according to the global trend in social investment programs. However, the supposed benefits of such have been sacrificed on the altar of politics. Hence, most such programs end up in a small community of political supporters. At the expiration of the tenure of such a government, the programs are mostly starved to death. Thus, the lack of sustainability of social protection policies and programs in Nigeria has left the country to attain the unenviable capital of poverty in the world by the latest global poverty index. 

Africa

The present government's efforts to redeem the country's image abroad and improve the living condition of the Nigerian masses are hardly known to have had any significant positive impacts. As of early 2020, about 40 percent are still extremely poor, living below the international standard of \$1 per day (World Bank, 2020, NBS, 2020). These statistics invariably indicate that the major problem with Nigeria is inequality. In this wise, a major concern then is: how are the social investment programs (N-SIP) bridging the gap between the poor and the rich in Nigeria on the one hand and the gap between Nigeria and the developed capitalist countries in the process of globalization?

In the 2018 Commitment to Reducing Inequality Index (CRI) compiled by Development Finance International (DFI) and Oxfam, Nigeria placed bottom in 157 nations. The CRI ranks the commitment of national governments to reducing the gap between rich and poor citizens by measuring three factors considered 'critical' to reducing the gap: social spending, tax policies, and labor rights. Nigeria ranked bottom of the index for the second consecutive year. The report notes that Nigeria's social spending (mainly on health, education, and social protection) is 'shamefully low', which is reflected in inferior social outcomes for its citizens, as shown below.

Table 2: Bottom 10 countries in the CRI Index ranking of157 countries

\begin{tabular}{|c|c|c|c|c|}
\hline & OVERALL CRI RANK & $\begin{array}{l}\text { SPENDING ON HEALTH, } \\
\text { EDUCATION AND } \\
\text { SOCIAL PROTECTION }\end{array}$ & $\begin{array}{l}\text { PROGRESSIVITY OF } \\
\text { TAX POLICY }\end{array}$ & $\begin{array}{l}\text { LABOUR RIGHTS AND } \\
\text { MINIMUM WAGES }\end{array}$ \\
\hline Bangladesh & 148 & 146 & 103 & 148 \\
\hline Singapore & 149 & 91 & 157 & 71 \\
\hline Lao POR & 150 & 153 & 44 & 146 \\
\hline Madagascar & 151 & 135 & 142 & 143 \\
\hline Bhutan & 152 & 81 & 153 & 147 \\
\hline Sierra Leone & 153 & 143 & 132 & 150 \\
\hline Chad & 154 & 145 & 138 & 154 \\
\hline Haiti & 155 & 133 & 145 & 156 \\
\hline Uzbekistan & 156 & 42 & 156 & 132 \\
\hline Nigeria & 157 & 157 & 104 & 133 \\
\hline
\end{tabular}

Source: Development Finance International and Oxfam Report (2018).

It appears that the inequality between the poor and the rich in Nigeria is a political creation at both supranational and national levels rather than a natural order. At the national level, the table 
PanAfrican Journal of Governance and Development, Vol. 2, No. 2, August 2021

below shows the salary and emoluments of Nigerian politicians in the national assembly compared to other politicians from some other countries.

Table 3: Annual salaries of legislators from different parts of the world

\begin{tabular}{|c|c|}
\hline Nigeria & $\$ 189,500$ \\
\hline United States & $\$ 174,000$ \\
\hline Brazil & $\$ 157,600$ \\
\hline UK & $\$ 105,400$ \\
\hline South Africa & $\$ 104,000$ \\
\hline France & $\$ 85,900$ \\
\hline Kenya & $\$ 74,500$ \\
\hline Saudi Arabia & $\$ 64,000$ \\
\hline Ghana & $\$ 46,500$ \\
\hline Indonesia & $\$ 65,800$ \\
\hline Thailand & $\$ 43,800$ \\
\hline India & $\$ 11,200$ \\
\hline Italy & $\$ 182,000$ \\
\hline Bangladesh & $\$ 4,000$ \\
\hline Israel & $\$ 114,800$ \\
\hline Hong Kong & $\$ 130,700$ \\
\hline Japan & $\$ 149,700$ \\
\hline Singapore & $\$ 154,000$ \\
\hline Canada & $\$ 154,000$ \\
\hline New Zealand & $\$ 112,500$ \\
\hline Germany & $\$ 119,500$ \\
\hline Ireland & $\$ 120,400$ \\
\hline Pakistan & $\$ 3,500$ \\
\hline Malaysia & $\$ 25,300$ \\
\hline Sweden & $\$ 99,300$ \\
\hline Sri Lanka & $\$ 5,100$ \\
\hline
\end{tabular}



Africa

\section{Spain}

Norway

Source: Ngwu and Nwaigwe (2019).

The data above shows that Nigeria's politicians are hardly committed to bridging the inequality. The minimum wage in Nigeria has been stagnated at N18,000 (\$43.80) until a few months ago, when it was increased to $\mathrm{N} 30,000$ (\$72.99). In all intents and purposes adds no meaning to the basic and average standard of living where the neoliberal tax regime has been unleashed on the citizens. There are also the challenges of inflation and terrorism which impact seriously on the living standard of Nigerians.

The inequality phenomenon is also being reinforced by politicians who rely on it to achieve political ends, especially during electioneering processes towards perpetual retaining political power and patronage. Nigeria is a pseudo-capitalist economy as she makes her capital largely through rent from oil and not the production of a sort. It has remained dependent on the capitalist states. The politicians in charge of the country's finances and economy share this capital with little concern for the masses (Urama, Iloh \& Ekeocha, 2018). Their take home from the public treasury on a monthly basis is outrageous. More precisely, the Nigerian legislators' salaries and emoluments are known to be among the highest in the whole world (Awotokun, 2020, Oxfam, 2017, Denrele, 2013).

The corruption that has crept into the implementation of N-SIP has taken a toll on all facets of national life. The wife to Mr. President, Mrs. Aisha Buhari, raised the alarm on Saturday, May 25, 2019, in Abuja during an interactive program she organized for women at the Presidential Villa. In her words, the N500bn Social Investment Program of her husband's administration has failed 'woefully', especially in the North. Aisha, who hails from Adamawa State, said the situation in her home state, as far as the SIP implementation was concerned, was pathetic. She disclosed that though Mrs. Maryam Uwais, the Senior Special Assistant (SA) to the President who is directly in charge of the programs' implementation, informed her that 30,000 women would be beneficiaries in Adam was in a pathetic state, four years had passed, and there was not the SA had kept her word. She also cited Kano, a highly-populated northern state where the SA hails from, as another example where she believed the program has failed. 


\section{PanAfrican Journal of Governance and Development, Vol. 2, No. 2, August 2021}

The acting chairman of the Economic and Financial Crimes Commission (EFCC) in Nigeria has repeated the allegation recently during the 15th Anti-Corruption Situation Room organized by the Human and Environmental Development Agenda in Kaduna on Tuesday, September 25. Thereafter, he called on the civil society organizations to play a more active role in partnering with the commission to combat corruption, especially in the National Social Investment Program.

Stakeholders' perception of the timing of N-SIP reemergence and its implementation is critical in the assessment of the programs. It has been observed that the programs had gathered unusual momentum towards the 2019 general elections in February and March 2019. For instance, a breakdown of the amount disbursed from the inception of N-SIP showed that the sum of N79.98 bn was released in 2016, while N140bn and N250.84bn were released in the 2017 and 2018 fiscal years, respectively (Onuba, 2019). This was attributed to serve as a ploy to harvest votes from the actual and potential beneficiaries who would be lucky to be selected. There is also this notion that the programs, especially the cash transfers, are a mere scam as there are reported cases in which N-SIP coordinators from the headquarters in Abuja connived with some of their states and local government agents to impersonate the supposed beneficiaries on the government register thereby defrauding the real poor and needy.

Amidst these crises and controversies, Mrs.Uwais, the SSA to the President on N-SIP, has praised the implementation of the N-Power program, in which about 500,000 people spread across 774 Local Government Areas have been recruited to teach in public schools, act as health workers in primary health centers and as agriculture extension advisors to smallholder farmers in various communities. The National Home-Grown School Feeding Program, which was aimed at providing one nutritious, balanced meal for 200 school days in a year, has been able to reach over 9.7 million pupils. Through the Government Enterprise and Empowerment Program, about 1,681,491 loans have been made available to successful applicants in all states and the Federal Capital Territory.

This report above has generated more controversies, especially regarding the bogus number of beneficiaries, which is 44,588,628. In this regard, Buhari (2019) curiously recollected interacting recently with a 74-year-old man selling petty things in Kano, whom she asked how much is his capital, and he responded between N3,000 and N4,000. In Ebonyi's state, there is another instance where a mother cried out for almost losing her son, whom she claimed was forced into 
forty-one days of fasting after considering the poverty-stricken background and the failure of the government to live up to its promise of N5,000 to the poorest of the poor every month.

\section{Conclusion}

The poverty situation in Nigeria has been systematic, endemic, and chronic. Nigeria being a peripheral state, has been a victim of the international capitalist system. The need to mitigate the situation has prompted different policy interventions such as the social investments programs. Unfortunately, these programs have suffered major setbacks, owing to negative factors associated with their conception and implementation. This paper critiqued social investments programming in Nigeria, with particular reference to the endeavors of the current administration led by President Buhari. The paper posited that Nigeria's political elites had trivialized social investment initiatives by alienating the people from governance and exploiting their vulnerable material conditions for partisan gains through ad hoc material hand-outs, cash transfers, and sundry pseudo and unsustainable empowerment programs tied to political patronage and electoral exigencies. The paper submits the way forward in mainstreaming social investment programs into national development policy through an Act of the Parliament. In that regard, the following measures will be necessary:

$>$ Promulgation of a national economic empowerment and welfare policy (NEEWP) in order to mitigate the growing incidence of poverty and socio-economic insecurity in the country.

$>$ Mainstreaming of such policy through parliamentary procedures in order to ensure its statutory regularization and sustainability.

$>$ Incorporating the existing ad hoc poverty reduction cum social investment programs into the NEEWP to boost operational efficiency.

$>$ Professionalization of the administration of social investment programs in Nigeria in order to guard against politicization, nepotism, and abuse.

\section{References}

Ameh, J. (2019). N500bn social investment scheme has failed in the North -Aisha Buhari; https://punchng.com/n500bn-social-investment-scheme-has-failed-in-north-aishabuhari/ (retrieved August 10, 2020).

Awotokun, K. (2020). The Nigeria's presidentialism and the burden of profligacy in an inchoate constitutional democracy. Mediterranean Journal of Social Sciences, 2(5); DOI: https://doi.org/10.36941/mjss-2020-0053. 


\section{PanAfrican Journal of Governance and Development, Vol. 2, No. 2, August 2021}

Babalola, T. (2018). Poverty tracker: Raising the red flag. Proshare Economy. 1(18): 1-32.

Bardhan, PK \& Mookherjee, D. (2000). Capture and governance at local and national levels. American Economic Review, 90(2): 135-139

Barrera-Osorio, F., Bertrand, M., Linden, L., \& Perez-Calle, F. (2009). Improving the design of conditional transfer programs: Evidence from a randomized education experiment in Colombia. Unpublished manuscript.

Bebbington, A. (2006). Social movements and the politicization of chronic poverty policy. CPCR Working Paper 63. London: Institute of Development Policy and Management.

Britto, T. (2005). Recent Trends in the Development Agenda of Latin America: An Analysis of Conditional Cash Transfers. Brazil: Ministry of Social Development.

Busso, S. (2017). The de-politicization of social policy at the time of social investment: Mechanisms and distinctive features. The Open Journal of Socio-political Studies 10(2): 421-447.

Cantillon, B. (2011). The paradox of the social investment state: growth, employment and poverty in the Lisbon era. Journal of European Social Policy, 21(5): 432-449.

Centre for Democracy and Development (2019). An assessment of the effectiveness of government policies and programs on economic growth and development. https://media.africaportal.org/documents/An assessment of the effectiveness of government policies.pdf(retrieved August 18, 2020).

Corluy, V. \&Vandenbroucke, F. (2014). Individual employment, household employment and risk of poverty in the European Union: A decomposition analysis, In Cantillon, B., \&

F. Vandenbroucke (eds.). Reconciling Work and Poverty Reduction: How Successful Are European Welfare States? Oxford: Oxford University Press.

Cronert, A. \& Palme, J. (2017). Approaches to Social Investment and Their Implications for Poverty in Sweden and the European Union: Global challenges. CROP/UiB Global Working paper series. Axel Cronert/ Uppsala University.

Darmawan, R. (n.d). Elite capture in urban society: Evidence from Indonesia. Draft paper, Department of Economics. University of Goettingen. Germany: Platz der GöttingerSieben.

De Beer, P. (2007). Why work is not a panacea: a decomposition analysis of EU-15 countries. Journal of European Social Policy, 17(4): 375-388.

De la Porte, C. \& Jacobsson, K. (2012). Social Investment or recommodification? Assessing the employment policies of the EU member states, In Morel, N, Bruno, P. \& Palme, J. (eds.) Towards a Social Investment Welfare State? Bristol: The Policy Press.

Denrele, A. (2013). Nigerian-lawmakers-are-the-highest-paid-in-the-world. https://www.vanguardngr.com/2013/08/nigerian-lawmakers-are-the-highestpaid-in-the-world/ August 25, 2013 (retrieved August 11, 2020).

Development Bank of Nigeria (2017). Assessing the Financing Gap of Nigerian MSMEs and Emerging Corporates. Abuja: Federal Government of Nigeria.

Federal Ministry of Budget and National Planning (2017). Economic Recovery \& Growth Plan, 2017-2020. Abuja: Federal Government of Nigeria.

Easton, D. (1965). A Systems Analysis of Political Life. New York: Wiley.

Esping-Andersen, G., Gallie, D., Hemerijck, A. \& Myles, J. (2002). Why We Need a New Welfare State. Oxford: Oxford University Press.

Filmer, D., \& Schady, N. (2009a). Are there diminishing returns to transfer size in conditional 
cash transfers? Policy Research Working Paper 4999. Washington DC: World Bank.

Filmer, D., \& Schady, N. (2009b). School enrollment, selection and test scores. Policy Research Working Paper 4998. Washington DC: World Bank.

Fiszbein, A., Schady, N., Ferreira, F., Grosh, M., Kelleher, N., Olinto, P., \& Skoufias, E. (2009). Conditional Cash Transfers: Reducing Present and Future Poverty. Washington DC: World Bank.

Garcia, M. \& Moore, C. (2012). Cash Dividend: The Rise of Cash Transfer Programs in SubSaharan Africa. Washington D. C: World Bank.

Giddens, A. (1998). The Third Way: The Renewal of Social Democracy. Cambridge: Polity Press.

Glewwe, P., \& Olinto, P. (2004). Evaluating the Impact of Conditional Cash Transfers on Schooling: An experimental Analysis of Honduras' PRAF Program. Unpublished manuscript.

Harrisson, J. (2007). Bringing politics back into poverty analysis: Why understanding social relations matters more for policy on chronic poverty than measurement. CPRC Working Paper 77. Vancouver: School for International Studies. Simon Fraser University.

Idyorough, E. A. (2019). Lamentations on the politics of social welfare in Nigeria, In Kida, M. I. \& G. A. Genyi (Eds). Delivering Democratic Promises in Nigeria: Prospects and Challenges. Makurdi: Gwatex Publishers.

Igwe, O. (2005). Politics and Globe Dictionary. Aba: Eagle Publishers.

Isenyo, G. (2019). There is corruption in N-SIP program -Magu https://punchng.com/there-iscorruption-in-n-sip-program-magu/(retrieved July 3, 2021).

Jimoh, A. and Olanrewaju A. O. (2009). Nigeria, Capitalism and the Question of Equity. Anthropologist, II (4)

Kazeem, Y. (2018). Nigeria has become the poverty capital of the world. Retrieved from: https://qz.com/africa/1313380/nigerias-has-the-highest-rate-of-extreme-povertyglobally/ (accessed on: 09/09/2019).

Musgrave, M.K. \& Wong, S. (2016). Towards a more nuanced theory of elite capture in development projects. The importance of context and theories of power. Journal of Sustainable Development, 9(3): 87-103.

Nelson, M. \& Stephens, J. D. (2012). Do social investment policies produce better jobs? In Morel, N, Bruno, P. \& Palme, J. (eds.) Towards a Social Investment Welfare State? Bristol: The Policy Press.

Ngwu, E.C. (2012). The state and public policymaking in Nigeria: A study of the formulation and implementation of the Universal Basic Education (UBE) policy, 2000 - 2011. Unpublished Ph.D Seminar. Department of Political Science, University of Nigeria, Nsukka.

NSIO (2018). Investing in our people. A brief on the National Social Investment Programs in Nigeria. Abuja: National Social Investment Office.

Obanya, P. (2010). Planning and Managing Meaningful Access to Education: The Nigerian Experience. Paper presented at Department of Education Open Seminar Series, 2010 of Centre for International Education University of Sussex on January 25.

Okoli, AC \& Orinya, S. (2014). Political opportunism and crisis of governance in Nigeria: 


\section{PanAfrican Journal of Governance and Development, Vol. 2, No. 2, August 2021}

Implications for sustainable statecraft and development. International Journal of Development and Sustainability, 7(4):1477-1487.

Okoli, A. C. \& Ugwu, A. C. (2016). Materialism-cum-commodification of delegacy: A political economy of vote aale in 2014 PDP governorship primary in Nasarawa State, Nigeria. FULafia Journal of Humanities and Social Sciences, 1(1): 51-68.

Olaf van-Vliet \& Chen W. (2015). Social investment and poverty reduction: A comparative analysis across fifteen European countries. Journal of Social Policy. DOI: $10.1017 / \mathrm{S} 0047279415000070$.

Onuba, I. (2019). FG's social safety program gulps N471bn in three years. https://punchng.com/fgs-social-safety-program-gulps-n471bn-in-three-years/ (retrieved July 3,2021).

Onah, R. C. \& Olise, C. N. (2019). National Social Investment Program (NSIP) and sustainable poverty reduction in Nigeria: Challenges and prospects. Journal of Humanities and Social Science (IOSR-JHSS), 24(10): 20-31.

Ozor, C. O (2008). Development administration and the incorporation of less-developed countries into the global capitalist system, In Obi, E. A. et al. (eds). Readings on Comparative Public Administration. Onitsha: Bookpoint Educational Limited.

Oxfam, (2017). Inequality in Nigeria. https://www-cdn.oxfam.org/s3fspublic/file attachments/cr-inequality-in-nigeria-170517-en.pdf

Platteau, J. (2004). Monitoring elite capture in community-driven development. Development and Change, 35(2): 223-246.

Rawlings, L. B., \& Rubio, G. M. (2005). Evaluating the impact of conditional cash transfer programs. The World Bank Research Observer, 20(1): 29-55.

Report, D. F. (2018). Commitment to reducing inequality index. Retrieved February 2, 2020, from https://www.oxfamamerica.org/explore/research-publications/thecommitment-to-reducing-inequality-index-2018/: https://www.oxfamamerica.org

Rosenau, P. V. (2003). The competition paradigm: America's Romance with Conflict, Contest, and commerce. Lanham/ Maryland/ Oxford/ England: Rowman \& Littlefield Publishers, Inc.

Samson, M. (2013). Development Co-operation Report. Ending Poverty. OECD.

SparkNotes Editors. (2005). SparkNote on Karl Marx (1818-1883). Retrieved October 23, 2019, from http://www.sparknotes.com/philosophy/marx/

UNDP .(2018). Human Development Indices and Indicators: 2018 Statistical Update (Briefing note for countries on the 2018 Statistical Update [Nigeria]). Geneva: United Nations Development Program.

Vandenbroucke, F. \& Vleminckx, K. (2011). Disappointing poverty trends: is the social and investment state to blame? Journal of European Social Policy 21(5): 450-471.

Yomi, K. (2015). Nigeria has some of the world's highest paid lawmakers and this start-up wants to slash their pay. Quartz Africa. https://qz.com/africa/417192/nigeria-has-someof-the-worlds-highest-paid-lawmakers-and-this-start-up-is-trying-to-slash-theirpay/(retrieved July 3,2021).

World Bank (2018). World Poverty Clock. New York: World Bank.

World Bank (2020). Nigeria releases new report on poverty and inequality in the country. https://www.worldbank.org/en/programs/lsms/brief/nigeria-releases-new-reporton-poverty-and-inequality-in-country____(retrieved July 3, 2021). 